\title{
"I AM THOR/DUST DAHO": mnemonic devices used by the Paris Fire Brigade to teach initial measures in undertaking a CBRN event
}

\author{
Louise Giaume ${ }^{1 *} \mathbb{D}$, Yann Daniel ${ }^{1}$, Franck Calamai ${ }^{1}$, Clément Derkenne ${ }^{1}$, Romain Kedzierewicz ${ }^{1}$, Aude Demeny ${ }^{1}$, \\ Kilian Bertho ${ }^{1}$, Stéphane Travers ${ }^{2,3}$, Bertrand Prunet ${ }^{1,3}$ and Fréderic Dorandeu ${ }^{3,4}$
}

\section{Background}

In 2019, the Paris Fire Brigade described the chemical, biological, radiological, and nuclear chain of survival (CBRN-CS) to point out five essential tasks that first responders should perform in managing individuals in a CBRN situation [1]. These tasks are inseparable, and they should be performed in the following order (Fig. 1): 1. Spot decontamination to reduce toxicity and prevent the spread of contamination; 2. Early toxidrome recognition to warn and prepare the healthcare chain; 3. Early antidote administration to prevent death; 4. Thorough decontamination to protect the healthcare system; and 5. Evacuation and transport to the hospital to continue the medical management of casualties. The purpose of developing the CBRN-CS was to provide a pragmatic, didactic tool that could be used during a CBRN crisis by all first responders, of any profession, and that would be applicable to all CBRN situations.

In CBRN events, we face multiple challenges. Despite the indisputable, constant threat of real CBRN situations, fortunately, they are rare. Thus, most first responders have never been exposed to real CBRN situations. Moreover, first responders often have insufficient levels of training and knowledge, and few have the opportunity to attend CBRN training refresher courses or simulation courses [2]. We predict that a CBRN crisis will

*Correspondence: louise.giaume@pompiersparis.fr

${ }^{1}$ Emergency Medical Department, Paris Fire Brigade, 1 Place Jules Renard, 75017 Paris, France

Full list of author information is available at the end of the article cause mass disruption, especially for the healthcare system, more than mass destruction (except in the case of a nuclear device detonation). In these unusual situations, first responders will experience extreme stress, and they must face the dilemma of triage. The use of personal protective equipment can increase stress [3], and it alters communication between team members [4].

It is well known that stress affects cognitive performance $[5,6]$. Simulation studies conducted to test how clinicians deal with stressful scenarios have shown that performance can be affected by stress [7, 8]. In stressful situations, decision-making is most effective when those in charge have simple tools to help them remember the main tasks that must be performed.

\section{“I AM THOR": a mnemonic device}

In January 2020, we initiated a survey to evaluate the CBRN-CS as a cognitive tool in training first responders in Paris. We asked all participants to place the CBRN-CS items in the correct order, immediately after the course, and 6 months later. Our results from the first 74 participants, which included exclusively medical practitioners and nurses, showed that $84.7 \%$ could place all the CBRN-CS items in the correct order immediately after the course. However, 6 months later, only $55.5 \%$ of respondents (only 45 participants out of the initial 74) could reconstitute the CBRN-CS, with items in the correct order. Despite the small size of this test population, we concluded that we needed to improve our strategy for teaching the CBRN-CS. We aimed to make the CBRN-CS more accessible and original author(s) and the source, provide a link to the Creative Commons licence, and indicate if changes were made. The images or other third party material in this article are included in the article's Creative Commons licence, unless indicated otherwise in a credit line to the material. If material is not included in the article's Creative Commons licence and your intended use is not permitted by statutory regulation or exceeds the permitted use, you will need to obtain permission directly from the copyright holder. To view a copy of this licence, visit http://creativecommons.org/licenses/by/4.0/. The Creative Commons Public Domain Dedication waiver (http://creativeco mmons.org/publicdomain/zero/1.0/) applies to the data made available in this article, unless otherwise stated in a credit line to the data. 


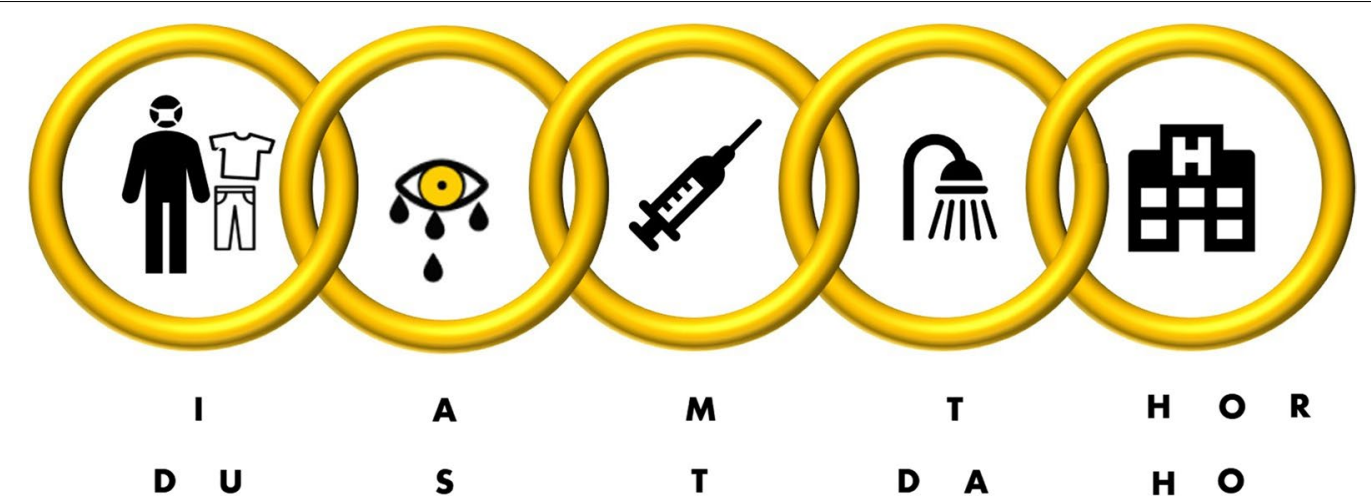

Fig. 1 The CBRN chain of survival: the five essential tasks that first responders should perform in managing individuals in a CBRN situation

easier to remember, especially under stressful and uncommon situations, which are rarely practiced.

Cognitive aids, like checklists or emergency manuals, can support clinicians in optimizing their actions during critical events [9]. In emergency settings, optimal implementation leads to better team communication [10] and improves compliance to the standard of care [11]. Mnemonic teaching is a pedagogic strategy that improves memorization, and this strategy frequently employs mnemonic devices. A mnemonic device can recap checklists, which is a hardy strategy for optimal performance in harsh environments. For example, since the 1990s, the US military has used the "MARCH" mnemonic to teach Tactical Combat Casualty Care (TCCC) [12]. In that mnemonic device, each letter corresponds to a term in the diagnosis and treatment protocol, in the correct order of relevance, for managing a war-injured individual [13]. A study conducted in the French military examined caregivers that were suddenly placed, without acclimation, in a highaltitude setting, where their pulse oximetry decreased. With this mnemonic, they could manage patients properly, without missing a significant intervention [14]. The dissemination of the TCCC approach, and its equivalents, among modern warfare personnel has improved the probability that individuals with warrelated injuries will arrive alive to the hospital [15].

Thus, based on this approach, we developed a French mnemonic device to make the CBRN-CS easier to remember. This device is called "I AM THOR", and its French translation is "DUST DAHO" (Table 1). It is currently taught in all CBRN training sessions to all first responders that might be involved in CBRN events. Henceforth, we will use it to complement the CBRN-CS cognitive aids. The next step will be to evaluate its efficiency among first responders.
Table 1 "I AM THOR/DUST DAHO": mnemonic devices for the CBRN chain of survival

\begin{tabular}{|c|c|c|c|}
\hline \multicolumn{2}{|c|}{ I AM THOR } & \multicolumn{2}{|c|}{ French version: DUST DAHO } \\
\hline । & Immediate decontamination & DU & Décontamination d'Urgence \\
\hline A & Assessment & $S$ & Symptômes \\
\hline M & Medication & $\mathrm{T}$ & Traitement \\
\hline $\mathrm{T}$ & Thorough decontamination & DA & Décontamination Approfondie \\
\hline $\mathrm{HO}$ & HOspital & $\mathrm{HO}$ & HOpital \\
\hline $\mathrm{R}$ & Re-evaluation & & \\
\hline
\end{tabular}

\section{Conclusion}

Our ability to recall learned information is often impaired, when acute stress, time pressure, and unfamiliarity are associated with the management of rare, high-acuity critical events, like CBRN situations. During the first few hours, whether they are on the scene or in front of the hospital, first responders must remember the appropriate response, share the same objectives, and coordinate their actions, regardless of their profession and the CBRN situation.

In CBRN events, appropriate, rapid actions are critical to curb disorganization and to optimize the management of injured individuals. Adding the mnemonic device "I AM THOR" to the CBRN-CS training could increase long-term memorization by first responders and help them initiate the main tasks required in any given CBRN situation.

\section{Abbreviations}

CBRN: Chemical, biological, nuclear, and radiological; CBRN-CS: Chemical, biological, nuclear, and radiological chain of survival; TCCC: Tactical Combat Casualty Care. 


\section{Acknowledgements}

None.

\section{Authors' contributions}

$L G$ and $Y D$ conceived the mnemonic device. $L G, Y D$, and FC drafted the manuscript. CD, FD, and BP contributed substantially to the revision of the manuscript. RK, AD, ST, and KB take responsibility for the paper as a whole. Al authors carefully read and approved the final manuscript.

\section{Funding}

This study was supported by institutional funding from the Emergency. Medical Department of the Paris Fire Brigade, Paris, France.

\section{Availability of data and materials}

Not relevant.

\section{Declarations}

Ethics approval and consent to participate

Not relevant.

\section{Consent for publication}

Not relevant.

\section{Competing interests}

The authors declare that they have no competing interests.

\section{Author details}

1 Emergency Medical Department, Paris Fire Brigade, 1 Place Jules Renard, 75017 Paris, France. ${ }^{2} 1$ re chefferie du service de Santé, French Military Health service, Villacoublay, France. ${ }^{3}$ Val-de-Grâce Military Health Academy, 1 Place Alphonse Laveran, 75005 Paris, France. ${ }^{4}$ French Military Biomedical Research Institute, French Military Health service, 91220 Bretigny-sur-Orge, France.

Received: 4 March 2021 Accepted: 8 March 2021

Published online: 22 March 2021

\section{References}

1. Calamai F, Derkenne C, Jost D, Travers S, Klein I, Bertho K, et al. The chemical, biological, radiological and nuclear (CBRN) chain of survival: a new pragmatic and didactic tool used by Paris Fire Brigade. Crit Care. 2019;23(1):66

2. Kako M, Hammad K, Mitani S, Arbon P. Existing approaches to chemical, biological, radiological, and nuclear (CBRN) education and training for health professionals: findings from an integrative literature review. Prehosp Disaster Med. 2018;33(2):182-90.
3. Blacker SD, Carter JM, Wilkinson DM, Richmond VL, Rayson MP, Peattie M. Physiological responses of Police Officers during job simulations wearing chemical, biological, radiological and nuclear personal protective equipment. Ergonomics. 2012;56(1):137-47.

4. Schumacher J, Arlidge J, Dudley D, Van Ross J, Garnham F, Prior K. First responder communication in CBRN environments: FIRCOM-CBRN study. Emerg Med J. 2019;36(8):456-8.

5. McMorris T, Hale BJ. Differential effects of differing intensities of acute exercise on speed and accuracy of cognition: a meta-analytical investigation. Brain Cogn. 2012;80(3):338-51.

6. Martin K, McLeod E, Périard J, Rattray B, Keegan R, Pyne DB. The impact of environmental stress on cognitive performance: a systematic review. Hum Factors. 2019;61(8):1205-46.

7. Harvey A, Bandiera G, Nathens AB, LeBlanc VR. Impact of stress on resident performance in simulated trauma scenarios. J Trauma Acute Care Surg. 2012;72(2):497-503.

8. Leblanc VR, Regehr C, Tavares W, Scott AK, Macdonald R, King K. The impact of stress on paramedic performance during simulated critical events. Prehosp Disaster Med. 2012;27(4):369-74.

9. Hannenberg AA. Cognitive aids in the management of critical events. Anesthesiol Clin. 2020;38(4):789-800.

10. Newkirk M, Pamplin JC, Kuwamoto R, Allen DA, Chung KK. Checklists change communication about key elements of patient care. J Trauma Acute Care Surg. 2012;73(2 Suppl 1):S75-82.

11. Lashoher A, Schneider EB, Juillard C, Stevens K, Colantuoni E, Berry WR, et al. Implementation of the World Health Organization trauma care checklist program in 11 centers across multiple economic strata: effect on care process measures. World J Surg. 2017;41(4):954-62.

12. Butler FKJ. Tactical combat casualty care: beginnings. Wilderness Environ Med. 2017;28(2S):S12-7

13. Kosequat J, Rush SC, Simonsen I, Gallo I, Scott A, Swats K, et al. Efficacy of the mnemonic device "MARCH PAWS" as a checklist for pararescuemen during tactical field care and tactical evacuation. J Spec Oper Med. 2017;17(4):80-4.

14. Depreux G, Melaine R, Ramdani E, Bourrilhon C, Wey P-F, Puidupin M et al. Les effets de l'hypoxie d'altitude sur la performance des équipes médicales pour la prise en charge des blessés de guerre. Medecine et Armées. 2013:41(5):437-40.

15. Kotwal RS, Montgomery HR, Kotwal BM, Champion HR, Butler FK, Mabry $\mathrm{RL}$, et al. Eliminating preventable death on the battlefield. Arch Surg. 2011;146(12):1350-8.

\section{Publisher's Note}

Springer Nature remains neutral with regard to jurisdictional claims in published maps and institutional affiliations.
Ready to submit your research? Choose BMC and benefit from:

- fast, convenient online submission

- thorough peer review by experienced researchers in your field

- rapid publication on acceptance

- support for research data, including large and complex data types

- gold Open Access which fosters wider collaboration and increased citations

- maximum visibility for your research: over 100M website views per year

At BMC, research is always in progress.

Learn more biomedcentral.com/submissions 